RESEARCH NOTE

\title{
NEW DATA ON SPECIES OF Demidospermus (DACTYLOGYRIDAE: MONOGE- NEA) PARASITIZING FISHES FROM THE RESERVOIR OF THE ITAIPU HYDROELECTRIC POWER STATION, PARANA STATE, BRAZIL, WITH NEW SYNONYMIES
}

\author{
SIMONE C. COHEN ${ }^{1}$; ANNA KOHN ${ }^{*}$
}

\begin{abstract}
COHEN, S.C.; KOHN, A. New Data on Species of Demidospermus (Dactylogyridae: Monogenea) Parasitizing Fishes from the Reservoir of the Itaipu Hydroelectric Power Station, Parana State, Brazil, With New Synonymies. [Novos dados sobre Demidospermus (Dactylogyridae: Monogenea) parasitas de peixes do reservatório da Usina Hidrelétrica de Itaipú, Estado do Paraná, Brasil, com novas sinonimias]. Revista Brasileira de Parasitologia Veterinária, v. 17, n. 3, p.167-170, 2008. Laboratório de Helmintos Parasitos de Peixes, Instituto Oswaldo Cruz, FIOCRUZ, Av. Brasil, 4365, Rio de Janeiro, RJ, 21045-900, Brazil. E-mail: annakohn@ioc.fiocruz.br

Eight known species of Demidospermus (Dactylogyridae, Monogenea) were collected from siluriform fishes from reservoir of the Itaipu Hydroelectric Power Station, Paraná, Brazil. Four of them are recorded for the first time in Brazil, enlarging their geographical distribution: Demidospermus armostus, Demidospermus anus, Demidospermus bidiverticulatum and Demidospermus valenciennesi. Demidospermus labrosi is synonymized with Demidospermus cornicinus and Demidospermus mandi with Demidospermus leptosynophallus and reported from two new hosts. Demidospermus paravalenciennesi and Demidospermus uncusvalidus were also collected.
\end{abstract}

KEY WORDS: Demidospermus, Monogenea, Siluriform fishes, Brazil, Itaipu Hydroelectric Power Station.

\section{RESUMO}

Oito espécies de Demidospermus (Dactylogyridae, Monogenea) foram coletadas de peixes Siluriformes do reservatório da Usina Hidrelétrica de Itaipú, Paraná, Brasil. Quatro dessas são registradas pela primeira vez no Brasil, aumentando sua distribuição geográfica: Demidospermus armostus, Demidospermus anus, Demidospermus bidiverticulatum e Demidospermus valenciennesi. Demidospermus labrosi é considerada sinônima de Demidospermus cornicinus e Demidospermus mandi sinônima de Demidospermus leptosynophallus e registradas em dois novos hospedeiros. Foram também coletados exemplates de Demidospermus paravalenciennesi e Demidospermus uncusvalidus.

${ }^{1}$ Laboratório de Helmintos Parasitos de Peixes, Instituto Oswaldo Cruz, FIOCRUZ, Av. Brasil, 4365, Rio de Janeiro, RJ, 21045-900, Brazil. E-mail: scohen@ioc.fiocruz.br and annakohn@ioc.fiocruz.br *Research fellow I “Conselho Nacional de Desenvolvimento Científico e Tecnológico, CNPq"
PALAVRAS-CHAVE: Demidospermus, Monogenea, Siluriformes, Brasil, Usina Hidrelétrica de Itaipú.

Species of Demidospermus have been described from siluriform hosts from Argentina and more recently, from Brazil, indicating the specificity of the genus with the fish order. In the present paper, we found eight species of Demidospermus parasitizing different host genera belonging to the families Pimelodidae, Heptapteridae, Loricariidae and Auchenipteridae.

The genus Demidospermus is characterized by having tandem gonads; counterclock-wise coiled male copulatory organ; sinistral vaginal aperture; U,W or V shaped haptoral bars; subspherical eye granules and a sheathlike accessory piece serving as a guide for the MCO (KRITSKY; GUTIÉRREZ, 1998). Up to now, fourteen species of the genus were described from eight different species of siluriform fishes. 
The order Siluriformes is a large, diverse order of fish, collectively known as catfish. Most of them are omnivores and unlike most freshwater fishes, many are nocturnal and depend mainly on senses other than sight, such as tactile and chemosensitive barbels. They are preadapted to life in caves, aquifers and deep river channels (LUNDBERG; FRIEL, 2003). Fishes belonging to this order present a high index of parasitism, represented by the different groups of helminths (KOHN et al., 2004).

Specimens of the hosts, Iheringichthys labrosus (Lütken, 1874), Pimelodus maculatus Lacépède, 1803, Pimelodus sp. (Pimelodidae), Pimelodella sp. (Heptapteridae), Loricariichthys platymetopon Isbrücker and Nijssen, 1979 (Loricariidae) and Auchenipterus osteomystax (Miranda-Ribeiro, 1919) (Auchenipteridae) were collected from 1991 through 1995 during expeditions to the reservoir of the Itaipu Hydroelectric Power Station (RIHPS) in the localities of "Foz do Iguaçu", "Santa Helena” and "Guaira”. The gills of the hosts were removed and placed in bowls containing 1:4000 formalin solution and shaked. Additional formalin was added to reach the concentration of $4 \%$. The parasites were collected and mounted unstained into slides with Hoyer's mounting medium or stained Gomori's trichrome and mounted in Canada balsam. Holotypes and paratypes of Demidospermus labrosi and Demidospermus mandi deposited at the Helminthological Collection of "Instituto Oswaldo Cruz" (CHIOC) were examined. Photomicrographies were taken with a digital camera Sony acopled at Axioskop light microscope. Observations were made also using a confocal laser scanning microscope Zeiss LSM 510 (CSLM). Slides of studied specimens were deposited at CHIOC.

Suriano (1983) proposed the genus Demidospermus for $D$. anus, parasite from the gills of Loricariichthys anus (Valenciennes, 1835) (=Loricaria anus) from the Laguna de Chascomus, Buenos Aires, Argentina. Gutierrez and Suriano (1992) described three new species from the Río de la Plata, Buenos Aires, Argentina: Demidospermus paravalenciennesi described from Synodontis clarias (Linnaeus) (= Pimelodus clarias), later redescribed by Kritsky and Gutierrez (1998) from the same host and reported from Pimelodus maculatus by Gutierrez and Martorelli (1999), all from Argentina and recently referred in $P$. maculatus from Brazil (SANTOS et al., 2007); Demidospermus valenciennesi from Parapimelodus valenciennes (Lutken, 1874), previously referred in the same host and type locality and from Rio Uruguay near Colón, Entre Rios, Argentina by Kritsky and Gutierrez (1998); the third species, Demidospermus uncusvalidus, was originally described from Synodontis clarias and Trachelyopterus galeatus (Linnaeus, 1766) (= Parauchenipterus galeatus) and also referred by Kritsky and Gutierrez (1998) in S. clarias and in P. maculatus by Gutierrez and Martorelli (1999) from Argentina and by Santos et al. (2007) from Brazil. Kritsky and Gutierrez (1998) emended the diagnosis of the genus and proposed five new species, also from the Río de la Plata, Argentina: Demidospermus armostus from S. clarias, previously reported by Gutierrez and Martorelli (1999) and by Gutierrez (2001) in P. maculatus and Pimelodus albicans (Valenciennes, 1840) respectively, in the type locality; Demidospermus cornicinus and Demidospermus leptosynophallus from the gills of Bergiaria westermanii (Lutken, 1874) (=Iheringichthys westermanii); Demidospermus idolus and Demidospermus majusculus from the gills of P. albicans. Kritsky and Gutierrez (1998) considered Omothecium Kritsky, Thatcher and Boeger, 1987 and Paramphocleithrum Suriano and Incorvaia, 1995 as synonyms of Demidospermus, proposing three new combinations: Demidospermus bidiverticulatum (Suriano and Incorvaia, 1995) originally described from $P$. maculatus (=Pimelodus clarias maculatus) and referred by them in $S$. clarias and P. albicans, Demidospermus luckyi (Kritsky, Thatcher and Boeger, 1987) and Demidospermus pinirampi (Kritsky, Thatcher and Boeger, 1987) from Pinirampus pinirampi (Spix and Agassiz, 1829) from Amazonas, Brazil.

Eight known species of Demidospermus are reported from the reservoir of Itaipú Hydroelectric Power Station. From them, four species are recorded for the first time in Brazil, extending their geographical distribution: Demidospermus armostus from Pimelodus maculatus, Demidospermus anus Suriano, 1983 from Loricariichthys platymetopon, representing a new host record (Figures. 1-3), Demidospermus bidiverticulatum from Pimelodus maculatus, Pimelodus sp. and in a new host Auchenipterus osteomystax and Demidospermus valenciennesi collected from two new hosts, Pimelodus sp. and P. maculatus. Demidospermus paravalenciennesi and $D$. uncusvalidus were also collected from P. maculatus and Pimelodus sp.

Demidospermus cornicinus Kritsky and Gutierrez, 1998 is characterized by having the marginal hook pair 1 larger than the others with expanded shank and a flared termination of the male copulatory organ. Demidospermus labrosi França, Isaac and Pavanelli (2003) was originally described from Iheringichthys labrosus from the upper Paraná River foodplain, Brazil; the authors stated that this species is similar to D. cornicinus regarding the dorsal bar V shaped, dorsal and ventral anchors with poorly differentiated roots, vaginal vestibule presenting sclerotized ridges, but differs from it in the ventral bar, which presents a serrated internal margin and with a concavity and in the copulatory organ.

From examination of 228 Demidospermus specimens collected from I. labrosus, Pimelodus sp. and Pimelodella sp. and the holotype and paratypes of D. labrosi, we observed that the serrated margin of the ventral bar described by França et al. (2003) can be visualized or not, depending of its angular position (Figures. 4-6). We could not observe any difference in the morphology of the copulatory complex between $D$. labrosi and $D$. cornicinus. Depending on the image focus, the male copulatory organ can be observed as funnelshaped or with a flared termination (Figure 7). Considering the morphological characteristics cited above and similar measurements between the two species, we propose $D$. labrosi as a junior synonym of $D$. cornicinus.

We report Demidospermus cornicinus in two new hosts: 

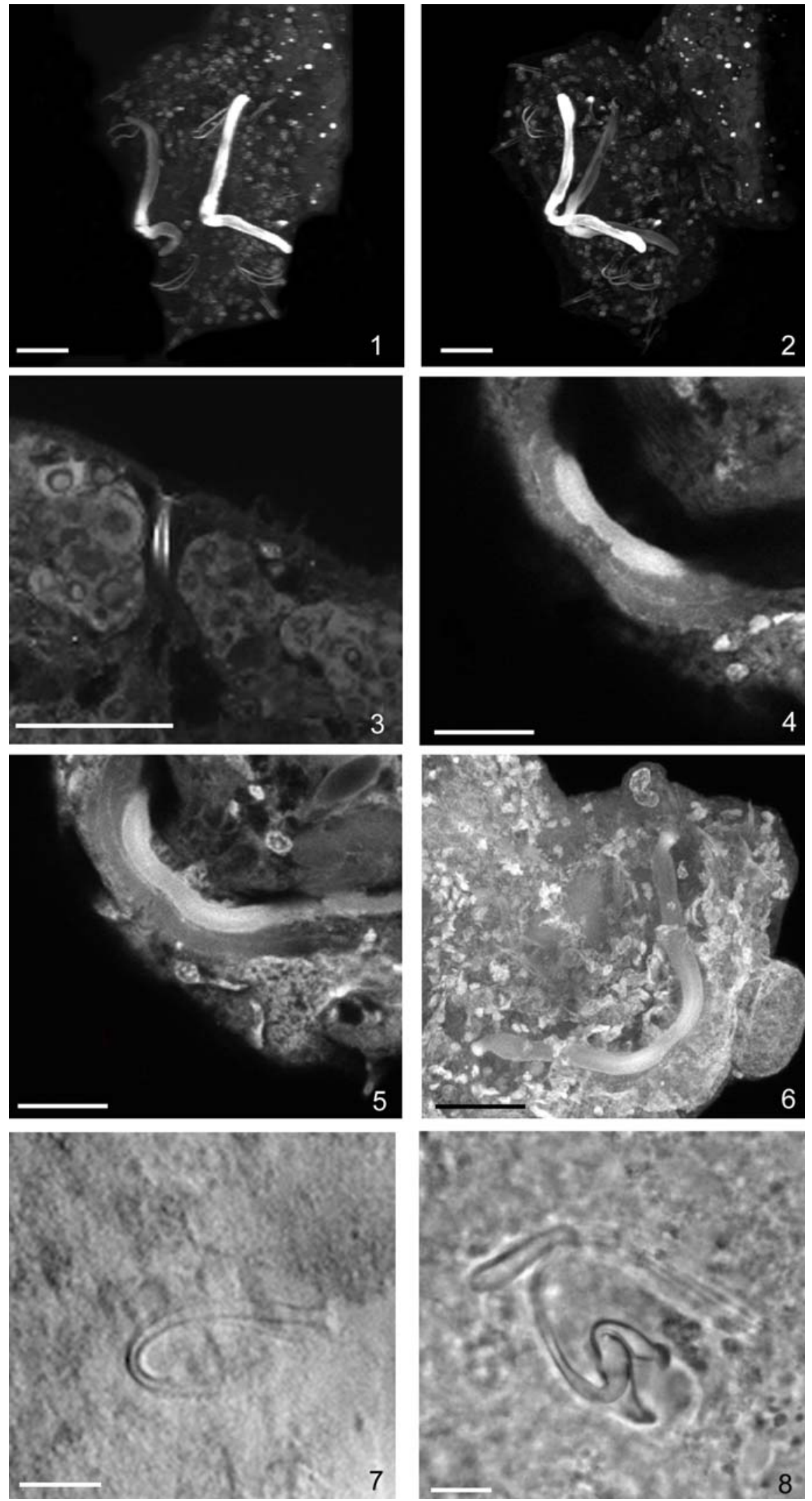

Figures 1-3. Demidospermus anus Suriano, 1983. 1-2. Haptor with dorsal bars, ventral bars and hooks (CSLM). 3. Detail of vagina (CSLM) Figures 4-7. Demidospermus cornicinus Kritsky and Gutierrez, 1998. 4-6. Detail of ventral bar (CSLM). 7. Light micrograph of the male copulatory complex. Figure 8. Demidospermus leptosynophallus Kritsky and Gutierrez, 1998. Light micrograph of the male copulatory complex. Scale bars: 1,2,4,5,7: $10 \mathrm{~mm}$; 3,6: $20 \mathrm{~mm}$; 8: $15 \mathrm{~mm}$. 
Pimelodus sp. and Pimelodella sp. and in a host previously referred in Brazil, by França et al. (2003), Iheringichthys labrosus.

Demidospermus leptosynophallus was described by Kritsky and Gutierrez (1998) and is characterized by the hook pairs 1,2 and 7 presenting dilated shank comprising 2 subunits and by the male copulatory complex J shaped and base with two sclerotized flaps. Demidospermus mandi França, Isaac and Pavanelli (2003) from the gills of I. labrosus from the upper Parana River, Brazil, was described with the male copulatory complex having the distal region forming a bulb, in which it was differentiated from D. leptosynophallus. Examining the holotype and paratypes of $D$. mandi, we observed similarity of the copulatory complex with our specimens (Fig. 8). This feature and morphometrical data in agreement lead us to consider $D$. mandi a junior synonym of $D$. leptosynophallus. This species was found parasitizing $I$. labrosus and two new hosts, Pimelodus sp. and Pimelodella sp.

\section{REFERENCES}

FRANÇA, J.G.; ISAAC, A.; PAVANELLI, G.C.; TAKEMOTO, R.M. Dactylogyridae (Monogenea) from the gills of Iheringichthys labrosus (Osteichthyes: Pimelodidae) from the upper Parana River foodplain, Brazil, with the proposal of Pseudovancleavus n.g. Systematic Parasitology, v. 54, n. 1, p. 25-31, 2003.

GUTIÉRREZ, P.A. Monogenean community structure on the gills of Pimelodus albicans from Río de la Plata (Argentina): a comparative approach. Parasitology, v.122, n. 4, p. 465-470, 2001.

GUTIÉRREZ, P.A.; MARTORELLI, S.R. The structure of the monogenean community on the gills of Pimelodus maculatus in Río de la Plata (Argentina). Parasitology, v. 119, n. 2, p. 177-182, 1999.

GUTIÉRREZ, P.A.; SURIANO, D.M. Ancyrocephalids of the genus Demidospermus Suriano, 1983 (Monogenea) parasites from Siluriform fishes in Argentina, with descriptions of three new species. Acta Parasitologica, v. 37, n. 4, p. 169-172, 1992.

KOHN, A.; FERNANDES, B.M.M.; BAPTISTA-FARIAS, M.F.D.; COHEN, S.C.; FERNANDEZ, D.R.; CANZI, C. Helmintos parasitas dos peixes dos reservatórios de Itaipú e área de influência. Revista Brasileira de Medicina Veterinária, v. 25, n. 4, p. 148-153, 2003.

KRITSKY, D.C.; GUTIÉRREZ, P.A. Neotropical Monogenoidea. 34. Species of Demidospermus (Dactylogyridae, Ancyrocephalinae) from the gills of Pimelodids (Teleostei, Siluriformes) in Argentina. Journal of the Helminthological Society of Washington, v. 65, n. 2, p. 147-159, 1998.

LUNDBERG, J.G.; FRIEL, J.P. Siluriformes, catfishes. Available on: <http://tolweb.org/Siluriformes/15065/ 2003.01.20> Access on: 20 Jan. 2003.

SANTOS, M.D.; LEMOS-PITA, S.R.L.; BRASIL-SATO, M.C. Metazoan parasite fauna of Pimelodus maculatus Lacépède, 1803 (Siluriformes: Pimelodidae) from the Guandu River, State of Rio de Janeiro, Brazil. Acta Scientiarium Biological Sciences, v. 29, n. 1, p. 101-107.

SURIANO, D.M. Demidospermus anus gen.nov. sp.nov. (Monogenea: Ancyrocephalinae) parasite branchial de Loricaria (L.) anus Valenciennes, 1840 (Pisces: Loricariidae) de la Laguna de Chascomus, Província de Buenos Aires, Republica Argentina. Neotropica, v. 29, p.111-119, 1983.

Received on December 06, 2007.

Accepted for publication on August 07, 2008. 